\title{
OPTIMIZATION OF CUTTING PARAMETERS FOR IMPROVING SURFACE ROUGHNESS IN TURNING OPERATION USING TAGUCHI METHOD AND ANOVA
}

\author{
Subhajit Dangar ${ }^{1}$, S Mukherjee ${ }^{2}$ \\ ${ }^{1}$ M.Tech Scholar, Department of Mechanical Engineering, Jalpaiguri Government Engineering College, West Bengal, \\ India \\ ${ }_{2}^{2}$ Professor, Department of Mechanical Engineering, Jalpaiguri Government Engineering College, West Bengal, India
}

\begin{abstract}
In the modern high-tech world the accuracy and finishing of a job are very important. In the present study the control parameters of a cast iron specimen undergoing turning operation are optimized so as to obtain minimum surface roughness. The parameters most responsible for surface roughness are identified and their working ranges are set. These parameters are spindle speed, feed rate and depth of cut. Experiments are conducted using parameter combinations obtained by Taguchi's L-9 orthogonal array and corresponding surface roughness are noted. S/N ratio calculations are done to find the significance order of the control parameters. Next analysis of variance (ANOVA) verifies the working ranges of the control parameters and their order of significance.
\end{abstract}

Keywords: Orthogonal array, ANOVA, S/N ratio, spindle speed, feed rate, depth of cut.

\section{INTRODUCTION}

Present days increasing the productivity and the quality of the machined parts (in terms of work piece dimensional accuracy, good surface finish, less wear of the cutting tools, high metal removal rate and economy of machining, cost per component and the performance of the product) are the main challenges of metal cutting industry during different machining processes. [1]The quality of design can be improved by improving the quality and productivity. Those activities concerned with quality, include quality of product planning, product design and process design.[2] Usually wear test, power consumption, material removal rate and surface finish are the most desirable tests for quality measurement of a machining process. Especially surface finish plays an important role on the product quality and it is a parameter of great importance in the evaluation of machining accuracy. In addition to surface finish quality, the tool wear and material removal rate are also importance characteristics in machining operation. In turning good surface finish, high material removal rate and low tool wear are desirable. Also dry turning is becoming important due to awareness towards the environment and worker's health. In addition to environment inputs, the cost associated with cutting fluid is approximately $7-17 \%$ of total manufacturing cost which is very high.[3],[4] The machining parameters such as cutting speed, feed and depth of cut, features of tool, work piece material and coolant conditions will highly affect these performance characteristics. Some researchers studied the effect of cutting conditions (V, F, D), [5],[6],[7] the influence of work piece hardness,[8],[9], the tool geometry, cutting time, cutting tool materials[10] and the effects of cutting fluid. It is necessary to select most appropriate machining settings to improve cutting efficiency, processing at low cost and to produce high quality products. [11]In the present study spindle speed, feed rate, depth of cut taken as the most important parameters affecting the surface roughness of the product undergoing turning operation.

\section{EXPERIMENTAL DETAILS}

\subsection{Degisn of Experiment}

To obtain the effect of the cutting parameters on surface roughness in the turning operation for cast iron metal work piece larger numbers of experiments are needed to be conducted. But with three parameters and three levels Taguchi's L9 Orthogonal array provides nine combinations for conducting experiments. Most influencing cutting parameters are spindle speed, feed rate and depth of cut. Levels of parameter are shown in table 1 and table 2 represents Taguchi's L9 Orthogonal Array. 
Table 1: levels of cutting parameters

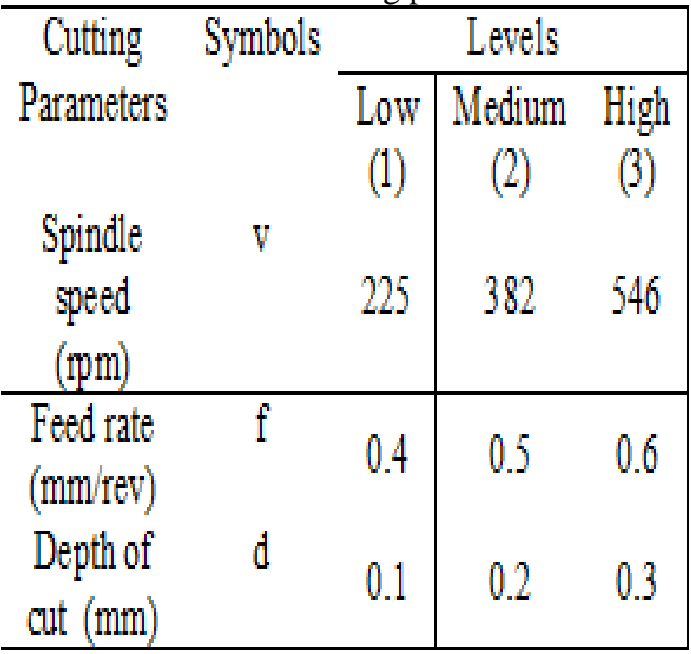

Table 2: Taguchi's L9 Orthogonal Array

\begin{tabular}{|c|c|c|c|}
\hline \multirow{2}{*}{ S1. No. } & \multicolumn{3}{|c|}{ Factorial Combination } \\
\cline { 2 - 4 } & $\mathrm{v}$ & $\mathrm{F}$ & $\mathrm{D}$ \\
\hline 1 & 1 & 1 & 1 \\
\hline 2 & 1 & 2 & 2 \\
\hline 3 & 1 & 3 & 3 \\
\hline 4 & 2 & 1 & 2 \\
\hline 5 & 2 & 2 & 1 \\
\hline 6 & 2 & 3 & 3 \\
\hline 7 & 3 & 1 & 3 \\
\hline 8 & 3 & 2 & 1 \\
\hline 9 & 3 & 3 & 2 \\
\hline
\end{tabular}

\subsection{Work piece Material and Cutting Inserts}

In this experiment turning operation is performed on cast iron bars of diameter $16 \mathrm{~mm}$ and length $40 \mathrm{~mm}$. For this experiment 9 jobs of same diameter and length taken according to Taguchi's L9 factorial combination. HSS cutting insert is used to perform the turning operation.

\subsection{Chemical Composition of Cast Iron}

\begin{tabular}{|l|l|l|l|l|}
\hline Element & Carbon & Silicon & Manganese & Others \\
\hline Percentage & 3.4 & 0.7 & 0.6 & Balance \\
\hline
\end{tabular}

\subsection{Experimental Procedure}

Nine jobs have been used for this experiment. Roughness measurement is been done using a portable stylus-type profilometer Talysurf (Taylor Hobson, Surtronic 3+, UK). Roughness measurements, in the transverse direction, on the work pieces have been repeated four times and average of four measurements are recorded. The measured profile has been digitized and processed through the advanced surface finish analysis software Talyprofile for evaluation of the roughness parameters.

\section{RESULTS AND DISCUSSION}

Table 3 shows the experimental data whereas table 4 and table 5 gives the $\mathrm{S} / \mathrm{N}$ ratio calculations

Table 3: Experimental Data

\begin{tabular}{|c|c|c|c|c|c|c|c|}
\hline \multirow{4}{*}{ Exp. No. } & \multicolumn{6}{|c|}{ Cutting parameters } & \multirow{3}{*}{$\begin{array}{c}\text { Surface } \\
\text { Roughness } \\
(\mu \mathrm{m})\end{array}$} \\
\hline & \multirow{2}{*}{\multicolumn{3}{|c|}{$\begin{array}{c}\text { Combination of cutting } \\
\text { parameters }\end{array}$}} & \multicolumn{3}{|c|}{ Actual values } & \\
\hline & & & & Spindle & Feed rate & Depth of cut & \\
\hline & 1 & 1 & 1 & 225 & 0.4 & 0.1 & 8.82 \\
\hline 2 & 1 & 2 & 2 & 225 & 0.5 & 0.2 & 9.08 \\
\hline 3 & 1 & 3 & 3 & 225 & 0.6 & 0.3 & 10.9 \\
\hline 4 & 2 & 1 & 2 & 382 & 0.4 & 0.2 & 12.8 \\
\hline 5 & 2 & 2 & 3 & 382 & 0.5 & 0.3 & 9.36 \\
\hline 6 & 2 & 3 & 1 & 382 & 0.6 & 0.1 & 12.74 \\
\hline 7 & 3 & 1 & 3 & 546 & 0.4 & 0.3 & 7.6 \\
\hline 8 & 3 & 2 & 1 & 546 & 0.5 & 0.1 & 6.16 \\
\hline 9 & 3 & 3 & 2 & 546 & 0.6 & 0.2 & 6.46 \\
\hline
\end{tabular}

For calculating $\mathrm{S} / \mathrm{N}$ ratio for smaller is better for surface roughness, the equation is

$$
\left[\mathrm{Y}_{\mathrm{i}}\right]=-10 \log _{10}\left[\Sigma\left(\mathrm{X}_{\mathrm{i}}^{2}\right) / \mathrm{n}\right]
$$

$\mathrm{Y}_{\mathrm{i}}=\mathrm{S} / \mathrm{N}$ ratio for respective result 
Table 4: $\mathrm{S} / \mathrm{N}$ ratio table for smaller is better

\begin{tabular}{|c|c|c|c|c|c|c|c|c|}
\hline \multirow[b]{3}{*}{$\begin{array}{c}\text { Ex } \\
\text { p. } \\
\text { no. }\end{array}$} & \multicolumn{6}{|c|}{ Turning parameter } & \multirow[b]{3}{*}{$\begin{array}{c}\text { Surfac } \\
\text { e } \\
\text { rough } \\
\text { ness } \\
(\mu \mathrm{m})\end{array}$} & \multirow[b]{3}{*}{$\begin{array}{c}\mathrm{S} / \mathrm{N} \\
\text { Ratio } \\
\text { for } \\
\text { smalle } \\
\mathrm{r} \text { is } \\
\text { better }\end{array}$} \\
\hline & \multirow{2}{*}{\multicolumn{3}{|c|}{$\begin{array}{l}\text { Combinati } \\
\text { on of } \\
\text { process } \\
\text { parameters }\end{array}$}} & \multicolumn{3}{|c|}{ Actual value } & & \\
\hline & & & & $\begin{array}{c}\text { Spin } \\
\text { dle } \\
\text { spee } \\
\text { d } \\
\text { (rpm }\end{array}$ & $\begin{array}{c}\text { Feed } \\
\text { rate } \\
(\mathrm{mm} / \mathrm{r} \\
\mathrm{ev})\end{array}$ & $\begin{array}{l}\text { Depth } \\
\text { of } \\
\text { Cut } \\
(\mathrm{mm})\end{array}$ & & \\
\hline 1 & 1 & 1 & 1 & 225 & 0.4 & 0.1 & 8.82 & $\begin{array}{c}- \\
18.90 \\
94 \\
\end{array}$ \\
\hline 2 & 1 & 2 & 2 & 225 & 0.5 & 0.2 & 9.08 & $\begin{array}{c}- \\
19.16 \\
17\end{array}$ \\
\hline 3 & 1 & 3 & 3 & 225 & 0.6 & 0.3 & 10.9 & $\begin{array}{c}- \\
20.74 \\
85 \\
\end{array}$ \\
\hline 4 & 2 & 1 & 2 & 382 & 0.4 & 0.2 & 12.8 & $\begin{array}{c}- \\
22.14 \\
22\end{array}$ \\
\hline 5 & 2 & 2 & 3 & 382 & 0.5 & 0.3 & 9.36 & $\begin{array}{c}- \\
19.42 \\
55 \\
\end{array}$ \\
\hline 6 & 2 & 3 & 1 & 382 & 0.6 & 0.1 & 12.74 & $\begin{array}{c}- \\
22.10 \\
34\end{array}$ \\
\hline 7 & 3 & 1 & 3 & 546 & 0.4 & 0.3 & 7.6 & $\begin{array}{c}- \\
17.61 \\
63 \\
\end{array}$ \\
\hline 8 & 3 & 2 & 1 & 546 & 0.5 & 0.1 & 6.16 & $\begin{array}{c}- \\
15.79 \\
16\end{array}$ \\
\hline 9 & 3 & 3 & 2 & 546 & 0.6 & 0.2 & 6.46 & $\begin{array}{c}- \\
16.20 \\
46\end{array}$ \\
\hline
\end{tabular}

Table 5: Overall mean of S/N ratio

\begin{tabular}{|c|c|c|c|c|}
\hline \multirow[b]{2}{*}{ Level } & \multicolumn{3}{|c|}{$\begin{array}{c}\text { Average S/N ratio by factor } \\
\text { level }\end{array}$} & \multirow[b]{2}{*}{$\begin{array}{c}\text { Overall } \\
\text { mean } \\
\text { of } \mathrm{S} / \mathrm{N} \\
\text { ratio }\left(\mathrm{Y}_{\mathrm{o}}\right)\end{array}$} \\
\hline & $\begin{array}{c}\text { Spindle } \\
\text { speed } \\
\text { (r.p.m.) }\end{array}$ & $\begin{array}{l}\text { Feed rate } \\
(\mathrm{mm} / \mathrm{rev} .)\end{array}$ & $\begin{array}{l}\text { Depth } \\
\text { of cut } \\
(\mathrm{mm})\end{array}$ & \\
\hline Low & -19.606 & -19.5560 & -18.934 & \multirow{5}{*}{-19.122} \\
\hline Medium & -21.223 & -18.1263 & -19.169 & \\
\hline High & -16.537 & -19.6855 & -19.263 & \\
\hline $\begin{array}{c}\text { Delta }=\text { larger- } \\
\text { smaller }\end{array}$ & 4.6862 & 1.5592 & 0.3286 & \\
\hline Rank & 1 & 2 & 3 & \\
\hline
\end{tabular}

From the above table it can be seen that spindle speed is the most influencing parameter followed by feed rate and depth of cut. And following graphs can be plotted from the results in Table 5.

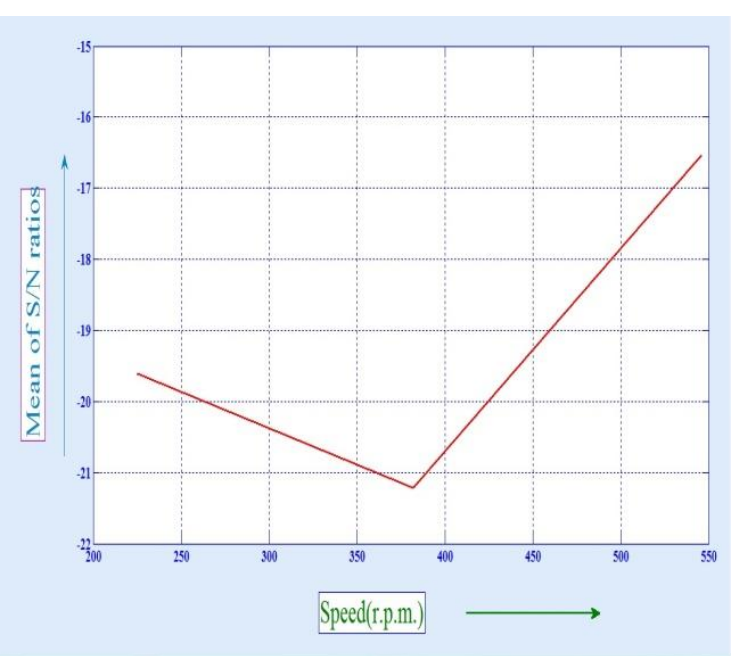

Fig.1: Variation of mean of $\mathrm{S} / \mathrm{N}$ ratio with spindle speed

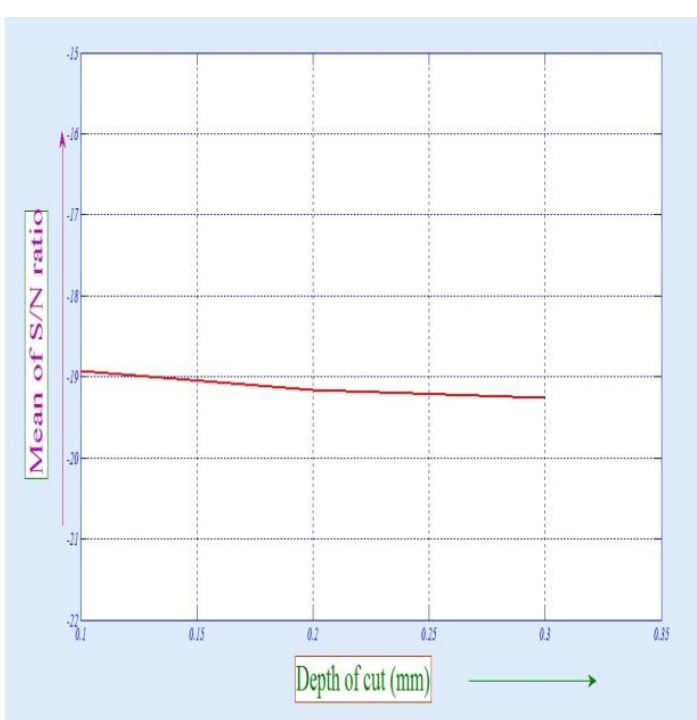

Fig.2: Variation of mean of $\mathrm{S} / \mathrm{N}$ ratio with depth of cut

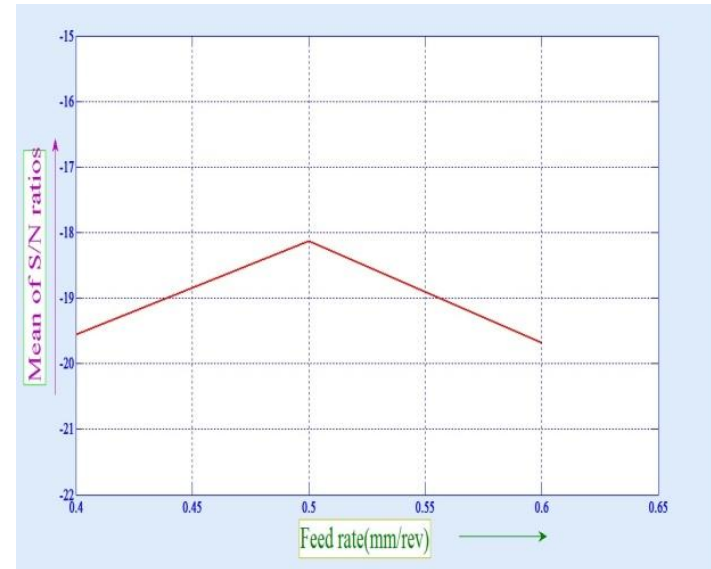

Fig.3: Variation of mean of $\mathrm{S} / \mathrm{N}$ ratio with feed rate 
Table 6: ANOVA calculation

\begin{tabular}{|c|c|c|c|c|c|}
\hline Factor & SS & Dof & MSE & $\begin{array}{c}\text { F } \\
\text { value }\end{array}$ & Contribution \\
\hline Spindle & 33.994 & 2 & 16.997 & 7.9753 & 0.7949 \\
\hline $\begin{array}{c}\text { Feed } \\
\text { Rate }\end{array}$ & 4.491 & 2 & 2.246 & 1.054 & 0.1050 \\
\hline $\begin{array}{c}\text { Depth } \\
\text { of cut }\end{array}$ & 0.172 & 2 & 0.086 & 0.0403 & 0.0040 \\
\hline Error & 4.262 & 2 & 2.131 & & \\
\hline Total & 42.766 & 8 & & & \\
\hline
\end{tabular}

\section{CONCLUSIONS}

The above calculations suggest that spindle speed has the largest influence with a contribution of $79 \%$. Next is feed rate with $10 \%$ contribution and depth of cut has lowest contribution of $0.04 \%$.

Hence it can be concluded that spindle speed has greatest effect on surface roughness followed by feed rate and depth of cut in the working ranges of the parameters considered for the purpose and surface roughness can be improved by proper combination of these parameters.

\section{ACKNOWLEDGEMENTS}

The authors wish to thank Asansol Engineering College for their supports in this work.

\section{REFERENCES}

[1]. S.R. Das, R.P. Nayak and D. Dhupal, "Optimization of Cutting Parameters on Tool Wear, Workpiece Surface Temperature and Material Removal Rate during Turning of AISI D2 Steel",International Journal of Engineering and Technology, Vol. 1, pp. 1-10, (2012).

[2]. R. Roy, Design of experiment using the Taguchi approach, John Wiley \& Sons, New York, (2001).

[3]. M.A. El Baradie, "Cutting Fluids, Part II: Recycling and clean machining", Journal of Materials Processing Technology, Vol. 56, pp. 798-806, (1996).

[4]. A.G. Jaharah, Mohd Nor AzmiMohdRodzi, A. Abdul Rahman, MohdNizamAbRahman and C. H. C. Hassan, "Machinability of FCD 500 ductile cast iron using coated carbide tool in dry machining condition", International J. of Mechanical and MaterialsEngineering, Vol. 4, pp. 279-284, (2009).

[5]. H. Singh, R. Khanna and M.P. Garg,"Effect of Cutting Parameters on MRR and Surface Roughness in Turning EN8",International J. of Current Engineering and Technology, Vol. 1, pp. 100-104, (2011).
[6]. H. Yanda, J.A.Ghani, M.A.M. Rodzi, K. Othman and C.H.C. Haron, "Optimization of material removal rate, surface roughness and tool life on conventional dry turning of FCD700", International Journal of Mechanical and Materials Engineering, Vol. 5, pp. 182-190, (2010).

[7]. V.S. Sharma, S. Dhiman, R. Sehgal and S.K. Sharma, "Assessment and optimization of cutting parameters while turning AISI 52100 steel", International J. of Precision and Manufacturing, Vol. 5, pp. 1-10, (2008).

[8]. M. N. Islam and Brian Boswell, "An Investigation of Surface Finish in Dry Turning", Proceedings of the World Congress on Engineering, London, pp. 1- 6, (2011).

[9]. T. Ozel, T.K. Hsu and E. Zeren, "Effects of cutting edge geometry, workpiece hardness, feed rate and cutting speed on surface roughness and forces in finish turning of hardened AISI H13 steel", I. J. Adv. Manufacturing Technology, Vol. 25, pp. 262-269, (2005).

[10]. M. Kaladhar, K. VenkataSubbaiah and C.SrinivasaRao, "Parametric optimization during machining of AISI 304 Austenitic Stainless Steel using CVD coated DURATOMICTM cutting insert", I. J. of Industrial Engineering Computations, Vol. 3, pp. 577-586, (2012).

[11]. S.R. Das, R.K. Behera, A. Kumar and D. Dhupal, "Experimental Investigation on Tool Wear, Surface Roughness and Material Removal Rate during DryTurning of AISI 52100 Steel", Journal Of Harmonized Research in Engineering, 1(1), 2013, 05-15

\section{BIOGRAPHIES}

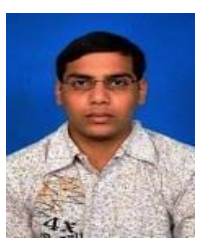

Subhajit Dangar, M.Tech. scholar Jalpaiguri Government Engineering College.

dangar1988@gmail.com

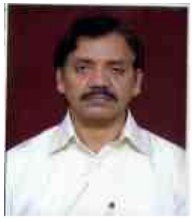

Dr. Sudip Mukherjee, Professor Mechanical engineering department, Jalpaiguri government engineering college sudipmukherji@rediffmail.com 